\title{
ON A THREE-PERSON SILENT MARKSMANSHIP CONTEST
}

\author{
Tadashi Kurisu \\ Osaka University
}

(Received August 16, 1979; Revised January 18, 1980)

\begin{abstract}
In this paper, we consider a three-person silent marksmanship contest. Each of three players 1,2 and 3 has a gun with exactly one bullet which may be fired at any time on $[0,1]$ aiming at his own target. The accuracy function $A_{i}(x)$ for player $i$ is strictly increasing and differentiable with $A_{i}(0)=0$ and $A_{i}(1)=1$. The first player hitting his target gets payoff +1 and other two players get payoff zero. For the game, we get a Nash equilibrium point and equilibrium payoff for each player. The form of the Nash equilibrium point differs whether $A_{1}(x) / A_{2}(x) A_{3}(x)$, $A_{2}(x) / A_{1}(x) A_{3}(x)$ and $A_{3}(x) / A_{1}(x) A_{2}(x)$ decrease or one of these increases. Some examples are given to illustrate the results.
\end{abstract}

\section{Introduction}

An $m$-person marksmanship contest is a non-zero-sum game with the following structure: There are $m$ players (i.e., contestants) 1, 2, .. , $m$ and $m$ targets, and each target is associated with one player. Every player has a gun with exactly one bullet which may be fired at any time in [0, 1] aiming at his own target. Starting at time 0 , each player walks toward his own target; he will reach his target at time 1 . If player $i$ fires his bullet at time $x$, the probability that he hits his target is $A_{i}(x)$. The function $A_{i}(x)$ is called the accuracy function for player $i$ and is strictly increasing and differentiable on $[0,1]$ with $A_{i}(0)=0$ and $A_{i}(1)=1$. The accuracy functions are fixed and known beforehand to all players. As soon as one of the players hits his target, the contest ends and the first player hitting his target gets payoff +1 and other players get payoff zero. If none of the players hit their targets or some players hit their targets at the same time, then the payoff is zero for every player. In this situation, each player wishes to delay firing as 1 ong as possible to increase his accuracy, while at the same time he does not wish to delay so long that his opponents can precede him with effectiveness. 
A marksmanship contest is noisy if each player knows when the others have fired and silent if neither player knows when the others have fired. Thus a noisy contest is the game with complete information in which each contestant is informed of his opponents' action, firing bullet, as soon as it takes place. On the other hand, in a silent contest each contestant is ignorant of any firing by the others.

The model is evidently m-person non-zero-sum game version of the duels. Silent duels were solved by Restrepo [4] and noisy duels were solved by Fox and Kimeldorf [1]. A more complete bibliography and a discussion of more general games of timing are found in Karlin [2]. Two-person noisy and silent marksmanship contests and $m$-person silent contest with equal accuracy functions were solved by Sakaguchi [5].

A Nash equilibrium point which is the most basic concept for non-cooperative $m$-person games is a set of strategies of the $m$ players, with the property that no player can improve his expectation by changing his own strategy, if the strategies of the others are held fixed (Nash [3]). For example, the set of strategies $\left(\mathrm{F}^{*}, \mathrm{G}^{*}, \mathrm{H}^{*}\right)$ is a Nash equilibrium point for a three-person game if and only if

$$
\begin{aligned}
& M_{1}\left(F^{*}, G^{*}, H^{*}\right) \geqq M_{1}\left(F, G^{*}, H^{*}\right), \\
& M_{2}\left(F^{*}, G^{*}, H^{*}\right) \geqq M_{2}\left(F^{*}, G, H^{*}\right)
\end{aligned}
$$

and

$$
\mathrm{M}_{3}\left(\mathrm{~F}^{*}, \mathrm{G}^{*}, \mathrm{H}^{*}\right) \geqq \mathrm{M}_{3}\left(\mathrm{~F}^{*}, \mathrm{G}^{*}, \mathrm{H}\right)
$$

for any strategies F, $G$ and $H$ of players 1, 2 and 3 , respectively, where $M_{i}(F, G, H)$ denotes the expected payoff for player $i$ when player 1 plays $F$, player 2 plays $G$ and player 3 plays $H$. Thus, each player's strategy is optimal against those of the others. We note that $\left(\mathrm{F}^{*}, \mathrm{G}^{*}, \mathrm{H}^{*}\right)$ is a Nash equilibrium point if and only if

$$
\begin{aligned}
& M_{1}\left(F^{*}, G^{*}, H^{*}\right) \geqq M_{1}\left(x, G^{*}, H^{*}\right), \\
& M_{2}\left(F^{*}, G^{*}, H^{*}\right) \geqq M_{2}\left(F^{*}, y, H^{*}\right)
\end{aligned}
$$

and

$$
\mathrm{M}_{3}\left(\mathrm{~F}^{*}, \mathrm{G}^{*}, \mathrm{H}^{*}\right) \geqq \mathrm{M}_{3}\left(\mathrm{~F}^{*}, \mathrm{G}^{*}, z\right)
$$

for any pure strategies $x, y$ and $z$ of players 1,2 and 3 , respectively. We further note that

$$
\mathrm{M}_{1}\left(x, \mathrm{G}^{*}, \mathrm{H}^{*}\right)=\mathrm{M}_{1}\left(\mathrm{~F}^{*}, \mathrm{G}^{*}, \mathrm{H}^{*}\right) \quad \text { for any } x \text { in }[a, b]
$$

if $\mathrm{F}^{*}$ has a density part over $[a, b]$ and similarly for $\mathrm{M}_{2}\left(\mathrm{~F}^{*}, y, \mathrm{H}^{*}\right)$ and $\mathrm{M}_{3}\left(\mathrm{~F}^{*}, \mathrm{G}^{*}, z\right)$.

\section{Formulation}


We consider the three-person silent marksmanship contest. There are three players 1, 2 and 3, and each player has a gun with exactly one bullet which may be fired at any time on $[0,1]$ aiming at his own target. The accuracy function for player $i$ is $A_{i}(x)$ with $A_{i}(0)=0$ and $A_{i}(1)=1$. As soon as one of the players hits his target, the contest ends and the first player hitting his target gets payoff +1 and other players get payoff zero. If none of the players hit their targets or some players hit their targets at the same time, then the payoff is zero for every player.

Since the contest is silent, none of the players can know whether the other players have fired their bullets or not. Furthermore, every player has only one byllet, and thus, a pure strategy for each player is determining his firing time. A mixed strategy for each player is a distribution function over $[0,1]$. Let $\bar{M}_{i}(x, y, z)$ be the expected payoff for player $i$ when players 1,2 and 3 fire their bullets at times $x, y$ and $z$, respectively. Then we have

$$
\overline{\mathrm{M}}_{1}(x, y, z)= \begin{cases}A_{1}(x), & x<\min (y, z), \\ A_{1}(x)\left\{1-A_{2}(y)\right\}, & y<x<z, \\ A_{1}(x)\left\{1-A_{3}(z)\right\}, & z<x<y, \\ A_{1}(x)\left\{1-A_{2}(y)\right\}\left\{1-A_{3}(z)\right\}, & \max (y, z)<x,\end{cases}
$$

and similarly for $\overline{\mathrm{M}}_{2}(x, y, z)$ and $\overline{\mathrm{M}}_{3}(x, y, z)$.

In this paper, we assume that $A_{1}(x) / A_{2}(x) A_{3}(x), A_{2}(x) / A_{1}(x) A_{3}(x)$ and $A_{3}(x) / A_{1}(x) A_{2}(x)$ are monotone. Then, it can be easily shown that at most one of these is monotone increasing, and so, we suppose that $A_{1}(x) / A_{2}(x) A_{3}(x)$ and $A_{2}(x) / A_{1}(x) A_{3}(x)$ are monotone decreasing.

3. The Case with Decreasing $A_{3}(x) / A_{1}(x) A_{2}(x)$

In this section, we assume that $A_{1}(x) / A_{2}(x) A_{3}(x), A_{2}(x) / A_{1}(x) A_{3}(x)$ and $A_{3}(x) / A_{1}(x) A_{2}(x)$ are strictly decreasing functions. Let us define a class of mixed strategies for three players in which we shall search for equilibrium strategies. We seek for a strategy for player $i(i=1,2$ and 3$)$ consisting of a density part $f_{i}(x)$ over the interval $[\alpha, 1]$ and a mass part $\alpha_{i}$ at $x=1$. We have with the normalization condition

$$
\int_{a}^{1} f_{i}(x) d x+\alpha_{i}=1 \quad \text { for } i=1,2 \text { and } 3 \text {. }
$$

We note that the function $f_{i}(x)$ may be zero on some interval in $[a, 1]$. Let $v_{i}$ $(i=1,2$ and 3$)$ be the equilibrium payoff of the game for player $i$. If player 1 fires his bullet at time $x$ in $[a, b]$ ( $b$ is determined later), then he gets 
payoff +1 if and only if

(i) each of players 2 and 3 does not hit his target before time $x$ and

(ii) the shoot of player 1 hits his target.

Thus, we have

$$
\mathrm{v}_{1}=A_{1}(x)\left\{1-\int_{a}^{x} A_{2}(y) f_{2}(y) d y\right\}\left\{1-\int_{a}^{x} A_{3}(y) f_{3}(y) d y\right\}
$$

for all $x$ in $[a, b]$. Similarly, we get

$$
\mathrm{v}_{2}=A_{2}(x)\left\{1-\int_{a}^{x} A_{1}(y) f_{1}(y) d y\right\}\left\{1-\int_{a}^{x} A_{3}(y) f_{3}(y) d y\right\}
$$

and

$$
\mathrm{v}_{3}=A_{3}(x)\left\{1-\int_{a}^{x} A_{1}(y) f_{1}(y) d y\right\}\left\{1-\int_{a}^{x} A_{2}(y) f_{2}(y) d y\right\}
$$

for all $x$ in $[a, b]$. From (1), (2) and (3), we get

$$
\mathrm{v}_{i}=A_{i}(a) \text {, }
$$

and thus,

$$
1-\int_{a}^{x} A_{i}(y) f_{i}(y) d y=\phi_{i}(x) / \phi_{i}(a)
$$

for all $x$ in $[a, b]$, where

and

$$
\begin{aligned}
& \phi_{1}(x)=\left\{A_{1}(x) / A_{2}(x) A_{3}(x)\right\}^{1 / 2}, \\
& \phi_{2}(x)=\left\{A_{2}(x) / A_{1}(x) A_{3}(x)\right\}^{1 / 2}
\end{aligned}
$$

$$
\phi_{3}(x)=\left\{A_{3}(x) / A_{1}(x) A_{2}(x)\right\}^{1 / 2} .
$$

By differentiating (5) with respect to $x$, we obtain

$$
f_{i}(x)=-\frac{\phi_{i}^{\prime}(x)}{A_{i}(x) \phi_{i}(a)} \quad \text { for a11 } x \text { in }[a, b] .
$$

We have assumed that $A_{1}(x) / A_{2}(x) A_{3}(x), A_{2}(x) / A_{1}(x) A_{3}(x)$ and $A_{3}(x) / A_{1}(x) A_{2}(x)$ are strictly decreasing, or equivalently, $\phi_{i}^{\prime}(x)<0$. Thus, we get $f_{i}(x)>0$ for all $x$ in $[a, b]$. It is easy to show that the equation

$$
-\int_{x}^{b} \frac{\phi_{i}^{\prime}(y)}{A_{i}(y)} d y=\phi_{i}(x)
$$

has a unique root in $[0, b]$ for any value of $b$ in $(0,1]$. Let $a_{i}$ be the unique root $a$ of the equation

$$
\int_{a}^{1} f_{i}(x) d x=1 .
$$


Without loss of generality, we assume $a_{1} \geqq a_{2} \geqq a_{3}$ and set $a=a_{2}$ and let $b$ be the unique root of the equation

$$
\int_{a}^{b} f_{1}(x) d x=1
$$

Then as player 1 has fired his bullet before time $b$, we have

$$
\mathrm{v}_{2}=A_{2}(x)\left\{1-\int_{a}^{b} A_{1}(y) f_{1}(y) d y\right\}\left\{1-\int_{a}^{x} A_{3}(y) f_{3}(y) d y\right\}
$$

and

$$
\mathrm{v}_{3}=A_{3}(x)\left\{1-\int_{a}^{b} A_{1}(y) f_{1}(y) d y\right\}\left\{1-\int_{a}^{x} A_{2}(y) f_{2}(y) d y\right\}
$$

for all $x$ in $(b, 1)$. It follows, from (4), (5) and (8), that

$$
f_{2}(x)=\frac{1}{\phi_{1}(b) \phi_{2}(a)} \frac{A_{3}^{\prime}(x)}{A_{2}(x) A_{3}(x)^{2}} \quad \text { for } b<x<1 .
$$

Similarly, we get

$$
f_{3}(x)=\frac{1}{\phi_{1}(b) \phi_{3}(a)} \frac{A_{2}^{\prime}(x)}{A_{2}(x)^{2} A_{3}(x)} \quad \text { for } b<x<1 .
$$

In this case, $\alpha_{1}=0$, and $\alpha_{2}, \alpha_{3}, a$ and $b$ are determined as follows:

$$
\begin{aligned}
& \int_{a}^{b} f_{1}(x) d x=1, \\
& \alpha_{i}=1-\int_{a}^{1} f_{i}(x) d x \quad i=2 \text { and } 3
\end{aligned}
$$

and

$$
\alpha_{2} \alpha_{3}=0 \text {. }
$$

Note that the simultaneous equations

$$
\left\{\begin{array}{l}
\int_{a}^{b} f_{1}(x) d x=1 \\
\int_{a}^{1} f_{i}(x) d x=1
\end{array} \quad(i=2 \text { or } 3)\right.
$$

have unique roots $a$ and $b$ if $a_{1} \geqq a_{2}$ and $a_{1} \geqq a_{3}$.

Theorem 1. Let us suppose that $A_{1}(x) / A_{2}(x) A_{3}(x), A_{2}(x) / A_{1}(x) A_{3}(x)$ and $A_{3}(x) / A_{1}(x) A_{2}(x)$ are strictly decreasing on $[0,1]$. Let $a_{i j}$ and $b_{i j}$ be the roots of the simultaneous equations 


$$
\left\{\begin{array}{l}
\int_{a_{i j}}^{b}{ }_{i j}(x) d x=\phi_{i}\left(a_{i j}\right) \\
\int_{a_{i j}}^{b} g_{j}(x) d x+\frac{1}{\phi_{i}\left(b_{i j}\right)} \int_{b_{i j}}^{1} g_{j k}(x) d x=\phi_{j}\left(a_{i j}\right)
\end{array}\right.
$$

( $1 \leqq i, j, k \leqq 3, i \neq j, i \neq k, j \neq k)$, where

and

$$
g_{i}(x)=-\phi_{i}^{\prime}(x) / A_{i}(x) \quad(i=1,2,3)
$$

$$
g_{j k}(x)=A_{k}^{\prime}(x) / A_{j}(x) A_{k}(x)^{2} \quad(1 \leqq j, k \leqq 3, j \neq k) .
$$

Let $a$ be the maximum value of $a_{i j}$ such that $0<a_{i j}<b_{i j} \leqq 1$ and let $b$ be the corresponding value of $b_{i j}$. Then a set of equilibrium strategies is given as follows:

(i) If $a=a_{1 j}$, then

$$
\begin{aligned}
& f_{1}^{*}(x)= \begin{cases}g_{1}(x) / \phi_{1}(a), & \text { for } a \leqq x \leqq b, \\
0, & \text { for } b<x \leqq 1,\end{cases} \\
& f_{2}^{*}(x)= \begin{cases}g_{2}(x) / \phi_{2}(x), & \text { for } a \leq x \leq b, \\
g_{23}(x) / \phi_{2}(a) \phi_{1}(b), & \text { for } b<x \leqq 1,\end{cases} \\
& f_{3}^{*}(x)= \begin{cases}g_{3}(x) / \phi_{3}(x) & \text { for } a \leqq x \leqq b, \\
g_{32}(x) / \phi_{3}(a) \phi_{1}(b), & \text { for } b<x \leqq 1,\end{cases}
\end{aligned}
$$

and $\alpha_{1}^{*}=0$. Moreover, if $\alpha=\alpha_{12}$, then $\alpha \frac{*}{2}=0$ and $\alpha_{3}^{*} \geq 0$ and if $a=a_{13}$, then $\alpha_{2}^{*} \geqq 0$ and $\alpha_{3}^{*}=0$.

(ii) If $a=a_{2 j}$, then

$$
\begin{aligned}
& f_{1}^{*}(x)= \begin{cases}g_{1}(x) / \phi_{1}(a), & \text { for } a \leqq x \leqq b, \\
g_{13}(x) / \phi_{1}(a) \phi_{2}(b), & \text { for } b<x \leqq 1,\end{cases} \\
& f_{2}^{*}(x)= \begin{cases}g_{2}(x) / \phi_{2}(a), & \text { for } a \leqq x \leqq b, \\
0, & \text { for } b<x \leqq 1,\end{cases} \\
& f_{3}^{*}(x)= \begin{cases}g_{3}(x) / \phi_{3}(a), & \text { for } a \leqq x \leqq b, \\
g_{31}(x) / \phi_{3}(a) \phi_{2}(b), & \text { for } b<x \leqq 1,\end{cases}
\end{aligned}
$$

and $\alpha_{2}^{*}=0$. Moreover, if $\alpha=\alpha_{21}$, then $\alpha_{1}^{*}=0$ and $\alpha_{3}^{*} \geqq 0$ and if $\alpha=\alpha_{23}$, then $\alpha_{1}^{*} \geqq 0$ and $\alpha_{3}^{*}=0$.

(iii) If $a=a_{3 j}$, then

$$
f_{1}^{*}(x)= \begin{cases}g_{1}(x) / \phi_{1}(a), & \text { for } a \leq x \leq b, \\ g_{12}(x) / \phi_{1}(a) \phi_{3}(b), & \text { for } b<x \leq 1,\end{cases}
$$




$$
\begin{aligned}
& f_{2}^{*}(x)=\left\{\begin{array}{l}
g_{2}(x) / \phi_{2}(a), \\
g_{21}(x) / \phi_{2}(a) \phi_{3}(b),
\end{array}\right. \\
& f_{3}^{*}(x)=\left\{\begin{array}{l}
g_{3}(x) / \phi_{3}(a), \\
0,
\end{array}\right.
\end{aligned}
$$$$
\begin{aligned}
& \text { for } a \leqq x \leqq b, \\
& \text { for } b<x \leqq 1, \\
& \text { for } a \leqq x \leqq b, \\
& \text { for } b<x \leqq 1,
\end{aligned}
$$

and $\alpha_{3}^{*}=0$. Moreover, if $a=a_{31}$, then $\alpha_{1}^{*}=0$ and $\alpha_{2}^{*} \geqq 0$ and if $a=a_{32}$, then $\alpha_{1}^{*} \geqq 0$ and $\alpha_{2}^{*}=0$.

In all these cases, the equilibrium payoff $v_{i}$ for player $i$ is $A_{i}(a)$.

Proof: Without loss of generality, we assume $a=a_{12}$. Let $M_{i}(x)$ be the expected payoff for player $i$ when he plays a pure strategy $x$ and other two players play the strategies described in Theorem 1 . We have already shown

and

$$
\begin{array}{ll}
\mathrm{M}_{1}(x)=A_{1}(a)=\mathrm{V}_{1} & \text { for } a \leqq x \leqq b, \\
\mathrm{M}_{2}(x)=A_{2}(a)=\mathrm{V}_{2} & \text { for } a \leqq x<1
\end{array}
$$

$$
\mathrm{M}_{3}(x)=A_{3}(\alpha)=\mathrm{V}_{3} \quad \text { for } a \leqq x<1 .
$$

It is easy to see, for $i=1,2$ and 3 , that

$$
M_{i}(x)=A_{i}(x)<A_{i}(a)=v_{i} \quad \text { for all } x \text { in }[0, a) .
$$

Furthermore, we have

and

$$
\begin{aligned}
& \mathrm{M}_{1}(1)=\left\{1-\int_{a}^{1} A_{2}(y) f_{2}^{*}(y) d y\right\}\left\{1-\int_{a}^{1} A_{3}(z) f_{3}^{*}(z) d z-\alpha_{3}^{*}\right\} \leq \mathrm{v}_{1}, \\
& \mathrm{M}_{2}(1)=\left\{1-\int_{a}^{1} A_{1}(x) f_{1}^{*}(x) d x\right\}\left\{1-\int_{a}^{1} A_{3}(z) f_{3}^{*}(z) d z-\alpha_{3}^{*}\right\} \leqq \mathrm{v}_{2}
\end{aligned}
$$

$$
\mathrm{M}_{3}(1)=\left\{1-\int_{a}^{1} A_{1}(x) f_{1}^{*}(x) d x\right\}\left\{1-\int_{a}^{1} A_{2}(y) f_{2}^{*}(y) d y\right\}=v_{3} .
$$

For $b<x<1$, we get

$$
\begin{aligned}
\mathrm{M}_{1}(x) & =A_{1}(x)\left\{1-\int_{a}^{x} A_{2}(y) f_{2}^{*}(y) d y\right\}\left\{1-\int_{a}^{x} A_{3}(z) f_{3}^{*}(z) d z\right\} \\
& =A_{1}(x) \frac{1}{\phi_{2}(a) \phi_{1}(b)} \frac{1}{A_{3}(x)} \frac{1}{\phi_{3}(a) \phi_{1}(b)} \frac{1}{A_{2}(x)} \\
& =\frac{A_{1}(x)}{A_{2}(x) A_{3}(x)} \frac{A_{2}(b) A_{3}(b)}{A_{1}(b)} A_{1}(a)<A_{1}(a)=v_{1}
\end{aligned}
$$

since $A_{1}(x) / A_{2}(x) A_{3}(x)$ is decreasing. Thus, for $i=1,2$ and 3 , we have

$$
\mathrm{M}_{i}(x) \leqq A_{i}(\alpha)=\mathrm{v}_{i} \quad \text { for all } x \text { in }[0,1] .
$$

This terminates our proof. 
From Theorem 1, it is seen that, if three players play the equilibrium strategies, one of the players fires his bullet over the time interval $[a, b]$ and another player fires over the time interval $[a, 1]$ and the remaining player fires over the same interval $[a, 1]$ and at time 1 with some probability which may be zero. This is a generalization of the results for the two-person silent contest.

4. The Case with Increasing $A_{3}(x) / A_{1}(x) A_{2}(x)$

In this section, we assume that $A_{3}(x) / A_{1}(x) A_{2}(x)$ is monotone increasing. We shall seek for a Nash equilibrium point in the following class of strategies:

(i) Player $i$ ( $i=1$ and 2 ) fires his bullet at time $x$ belonging to the time interval $[a, 1]$ according to the density function $f_{i}(x)$ and at time 1 . with probability $\alpha_{i}$.

(ii) Player 3 fires his bullet at time $x$ belonging to the time interval $[b, 1]$ where $a<b$ according to the density function $f_{3}(x)$ and at time 1 with probability $\alpha_{3}$.

We have with the normalizing conditions

$$
\int_{a}^{1} f_{i}(x) d x+\alpha_{i}=1 \quad \text { for } i=1 \text { and } 2
$$

and

$$
\int_{b}^{1} f_{3}(x) d x+\alpha_{3}=1
$$

As before, we set $v_{i}(i=1,2$ and 3$)$ be the equilibrium payoff of the game for player $i$. Then, since player 3 does not fire until time $b$, we have

$$
\mathrm{v}_{1}=A_{1}(x)\left\{1-\int_{a}^{x} A_{2}(y) f_{2}(y) d y\right\}
$$

and

$$
\mathrm{v}_{2}=A_{2}(x)\left\{1-\int_{a}^{x} A_{1}(y) f_{1}(y) d y\right\}
$$

for $a \leqq x \leqq b$. Therefore, we get

and thus,

$$
\mathrm{v}_{i}=A_{i}(\alpha) \quad \text { for } i=1 \text { and } 2 \text {, }
$$

$$
f_{1}(x)=\frac{A_{2}(a) A_{2}^{\prime}(x)}{A_{1}(x) A_{2}(x)^{2}} \quad \text { for } a \leqq x \leqq b
$$


and

$$
f_{2}(x)=\frac{A_{1}(a) A_{1}^{\prime}(x)}{A_{1}(x)^{2} A_{2}(x)} \quad \text { for } a \leqq x \leqq b .
$$

Let $\alpha_{1}$ and $\alpha_{2}$ be the unique roots of the equations

$$
\int_{a}^{b} f_{1}(x) d x=1 \quad \text { and } \quad \int_{a}^{b} f_{2}(x) d x=1
$$

respectively. Without loss of generality, we assume $a_{1} \geqslant a_{2}$ and we set $a=a_{1}$ and $\alpha_{1}=0$. Since player 1 has fired his bullet before time $b$, we have

$$
\mathrm{v}_{2}=A_{2}(x)\left\{1-\int_{a}^{b} A_{1}(y) f_{1}(y) d y\right\}\left\{1-\int_{b}^{x} A_{3}(y) f_{3}(y) d y\right\}
$$

and

$$
\mathrm{v}_{3}=A_{3}(x)\left\{1-\int_{a}^{b} A_{1}(y) f_{1}(y) d y\right\}\left\{1-\int_{a}^{x} A_{2}(y) f_{2}(y) d y\right\}
$$

for $b<x<1$. By means of (11), (12) and (13), (14) and (15) become as follows:

$$
\begin{aligned}
& A_{2}(b)=A_{2}(x)\left\{1-\int_{b}^{x} A_{3}(y) f_{3}(y) d y\right\} \\
& \mathrm{v}_{3}=\frac{A_{2}(a)}{A_{2}(b)} A_{3}(x)\left\{\frac{A_{1}(a)}{A_{1}(b)}-\int_{b}^{x} A_{2}(y) f_{2}(y) d y\right\}
\end{aligned}
$$

From (16), we have

$$
f_{3}(x)=\frac{A_{2}(b) A_{2}^{\prime}(x)}{A_{2}(x)^{2} A_{3}(x)} \quad \text { for } b \leqq x<1
$$

and from (17), we get

and

$$
\mathrm{v}_{3}=\frac{A_{1}(a) A_{2}(a) A_{3}(b)}{A_{1}(b) A_{2}(b)}
$$

$$
f_{2}(x)=\frac{A_{1}(a) A_{3}(b)}{A_{1}(b)} \frac{A_{3}^{\prime}(x)}{A_{2}(x) A_{3}(x)^{2}} \quad \text { for } b<x<1
$$

In this case, $\alpha_{2}, \alpha_{3}, a$ and $b$ are determined as follows:

$$
\begin{aligned}
& \int_{a}^{b} f_{1}(x) d x=1, \\
& \alpha_{2}=1-\int_{a}^{i} f_{2}(x) d x,
\end{aligned}
$$




$$
\begin{aligned}
& \alpha_{3}=1-\int_{b}^{1} f_{3}(x) d x, \\
& \alpha_{2} \alpha_{3}=0 .
\end{aligned}
$$

We note that the simultaneous equations

$$
\left\{\begin{array} { l } 
{ \int _ { a } ^ { b } f _ { 1 } ( x ) d x = 1 } \\
{ \int _ { a } ^ { 1 } f _ { 2 } ( x ) d x = 1 }
\end{array} \quad \text { and } \quad \left\{\begin{array}{l}
\int_{a}^{b} f_{1}(x) d x=1 \\
\int_{b}^{1} f_{3}(x) d x=1
\end{array}\right.\right.
$$

have unique roots $a$ and $b$.

Theorem 2. Let us suppose that $A_{3}(x) / A_{1}(x) A_{2}(x)$ is increasing over $[0,1]$. Let $a_{i j}$ and $b_{i j}(1 \leqq i, j \leqq 2, i \neq j)$ be the roots of the simultaneous equation

$$
\left\{\begin{array}{l}
\int_{a_{i j}{ }_{i j} g_{i j}(x) d x=\frac{1}{A_{j}\left(a_{i j}\right)}} \\
\int_{a_{i j}{ }_{i j} g_{j i}(x) d x+\frac{A_{3}\left(b_{i j}\right)}{A_{i}\left(b_{i j}\right)} \int_{b_{i j}}^{1} g_{j 3}(x) d x=\frac{1}{A_{i}\left(a_{i j}\right)}}
\end{array}\right.
$$

and let $a_{i 3}$ and $b_{i 3}(1 \leq i \leqq 2)$ be the roots of the simultaneous equation

$$
\left\{\begin{array}{l}
\int_{a_{i 3}}^{b} g_{i 3-i}(x) d x=\frac{1}{A_{3-i}{ }^{\left(a_{i 3}\right)}} \\
\int_{b_{i 3}}^{1} g_{33-i}(x) d x=\frac{1}{A_{3-i}{ }^{\left(b_{i 3}\right)}},
\end{array}\right.
$$

where

$$
g_{i j}(x)=A_{j}^{\prime}(x) / A_{i}(x) A_{j}(x)^{2} .
$$

Let $a$ be the maximum value of $a_{i j}$ such that $0<a_{i j}<b_{i j} \leqq 1$ and let $b$ be the corresponding value of $b_{i j}$. Then a set of equilibrium strategies is given as follows :

(i) If $a=a_{1 i}$, then

$$
\begin{aligned}
& f_{1}^{*}(x)= \begin{cases}A_{2}(a) g_{12}(x), & \text { for } a \leq x \leq b, \\
0, & \text { for } b<x \leq 1,\end{cases} \\
& f_{2}^{*}(x)= \begin{cases}A_{1}(a) g_{21}(x), & \text { for } a \leq x \leq b, \\
\frac{A_{1}(a) A_{3}(b)}{A_{1}(b)} g_{23}(x), & \text { for } b<x \leq 1,\end{cases}
\end{aligned}
$$




$$
f_{3}^{*}(x)= \begin{cases}0, & \text { for } a \leq x \leq b, \\ A_{2}(b) g_{32}(x), & \text { for } b<x \leq 1,\end{cases}
$$

and $\alpha_{1}^{*}=0$. Moreover, if $a=a_{12}$, then $\alpha_{2}^{*}=0$ and $\alpha_{3}^{*} \geqq 0$ and if $a=a_{13}$, then $\alpha_{2}^{*} \geqq 0$ and $\alpha_{3}^{*}=0$.

(ii) If $a=a_{2 i}$, then

$$
\begin{aligned}
& f_{1}^{*}(x)= \begin{cases}A_{2}(a) g_{12}(x), & \text { for } a \leqq x \leqq b, \\
\frac{A_{2}(a) A_{3}(b)}{A_{2}(b)} g_{13}(x), & \text { for } b<x \leqq 1,\end{cases} \\
& f_{2}^{*}(x)= \begin{cases}A_{1}(a) g_{21}(x), & \text { for } a \leqq x \leqq b, \\
0, & \text { for } b<x \leqq 1,\end{cases} \\
& f_{3}^{*}(x)= \begin{cases}0, & \text { for } a \leqq x \leqq b, \\
A_{1}(b) g_{31}(x), & \text { for } b<x \leqq 1,\end{cases}
\end{aligned}
$$

and $\alpha_{2}^{*}=0$. Moreover, if $a=a_{21}$, then $\alpha_{1}^{*}=0$ and $\alpha_{3}^{*} \geqq 0$ and if $a=a_{23}$, then $\alpha_{1}^{*} \geq 0$ and $\alpha_{3}^{*}=0$.

In tinese two cases, the equilibrium payoff $\mathrm{V}_{i}$ for player $i$ is given as follows:

$$
\mathrm{v}_{1}=A_{1}(a), \quad \mathrm{v}_{2}=A_{2}(a), \quad \mathrm{v}_{3}=\frac{A_{1}(a) A_{2}(a) A_{3}(b)}{A_{1}(b) A_{2}(b)} \text {. }
$$

Proof: Without loss of generality, we assume $a=a_{12}$. Let $M_{i}(x)$ be the expected payoff for player $i$ when he plays a pure strategy $x$ and other two players play the strategies described in Theorem 2. It is easy to see, for $i$ $=1$ and 2 , that

We have shown

$$
M_{i}(x)=A_{i}(x)<A_{i}(a)=\mathrm{V}_{i} \quad \text { for } 0 \leqq x<a .
$$

and

$$
\mathrm{M}_{1}(x)=A_{1}(a)=\mathrm{V}_{1} \quad \text { for } a \leqq x \leqq b
$$

$$
\mathrm{M}_{2}(x)=A_{2}(a)=\mathrm{V}_{2} \quad \text { for } a \leqq x<1 .
$$

Since $A_{1}(x) / A_{2}(x) A_{3}(x)$ is decreasing, we have

$$
\begin{aligned}
\mathrm{M}_{1}(x) & =A_{1}(x)\left\{1-\int_{a}^{x} A_{2}(y) f_{2}^{*}(y) d y\right\}\left\{1-\int_{b}^{x} A_{3}(y) f_{3}^{*}(y) d y\right\} \\
& =\frac{A_{1}(x)}{A_{2}(x) A_{3}(x)} \frac{A_{2}(b) A_{3}(b)}{A_{1}(b)} A_{1}(a) \leqq A_{1}(a)=\mathrm{v}_{1} \quad \text { for } b<x<1 .
\end{aligned}
$$

Moreover,

$$
\mathrm{M}_{1}(1)=\left\{1-\int_{a}^{1} A_{2}(y) f_{2}^{*}(y) d y\right\}\left\{1-\int_{b}^{1} A_{3}(y) f_{3}^{*}(y) d y-\alpha_{3}^{*}\right\} \leqq A_{1}(a)=v_{1}
$$


and

$$
\mathrm{M}_{2}(1)=\left\{1-\int_{a}^{b} A_{1}(y) f_{1}^{*}(y) d y\right\}\left\{1-\int_{b}^{1} A_{3}(y) f_{3}^{*}(y) d y-\alpha_{3}^{*}\right\} \leq A_{2}(\alpha)=v_{2} .
$$

Thus, we get

$$
\mathrm{M}_{i}(x) \leqq A_{i}(a)=\mathrm{v}_{i} \quad \text { for } i=1 \text { and } 2 \text {, and } 0 \leqq x \leqq 1 .
$$

We further obtain

$$
\mathrm{M}_{3}(x)=A_{3}(x) \leqq A_{3}(a) \leqq \frac{A_{1}(a) A_{2}(a) A_{3}(b)}{A_{1}(b) A_{2}(b)}=\mathrm{v}_{3} \quad \text { for } 0 \leqq x \leqq a,
$$

and

$$
\begin{aligned}
M_{3}(x) & =A_{3}(x)\left\{1-\int_{a}^{x} A_{1}(y) f_{1}^{*}(y) d y\right\}\left\{1-\int_{a}^{x} A_{2}(y) f_{2}^{*}(y) d y\right\} \\
& =A_{3}(x) \frac{A_{1}(a) A_{2}(a)}{A_{1}(x) A_{2}(x)} \leqq \frac{A_{1}(a) A_{2}(a) A_{3}(b)}{A_{1}(b) A_{2}(b)}=\mathrm{v}_{3} \quad \text { for } a \leqq x<b
\end{aligned}
$$

since $A_{3}(x) / A_{1}(x) A_{2}(x)$ is increasing. We have shown

$$
\mathrm{M}_{3}(x)=\frac{A_{1}(a) A_{2}(a) A_{3}(b)}{A_{1}(b) A_{2}(b)}=\mathrm{v}_{3} \quad \text { for } b \leq x<1
$$

and it is easy to see

$$
\begin{aligned}
\mathrm{M}_{3}(1) & =\left\{1-\int_{a}^{b} A_{1}(y) f_{1}^{*}(y) d y\right\}\left\{1-\int_{a}^{1} A_{2}(y) f_{2}^{*}(y) d y\right\} \\
& =\frac{{ }_{1}(a) A_{2}(a) A_{3}(b)}{A_{1}(b) A_{2}(b)}=\mathrm{v}_{3} .
\end{aligned}
$$

Thus, we get

$$
M_{3}(x) \leqq \frac{A_{1}(a) A_{2}(a) A_{3}(b)}{A_{1}(b) A_{2}(b)}=V_{3} \quad \text { for } 0 \leqq x \leqq 1 .
$$

This completes our proof.

5. Examples

We give some examples of three-person silent marksmanship contests.

Example 1. Let $A_{1}(x)=A_{2}(x)=A_{3}(x)=x$. Then

$$
f_{1}^{*}(x)=f_{2}^{*}(x)=f_{3}^{*}(x)=\frac{1}{2} a^{1 / 2} x^{-5 / 2} \quad \text { for } a \leq x \leq 1,
$$

where $a=0.2831$. Moreover, $v_{1}=v_{2}=v_{3}=0.2831$ and $\alpha_{1}^{*}=\alpha_{2}^{*}=\alpha_{3}^{*}=0$. This coincides with the result by Sakaguchi [5].

Example 2. Let $A_{1}(x)=A_{2}(x)=x$ and $A_{3}(x)=x^{3 / 2}$. Then 


$$
f_{1}^{*}(x)=f_{2}^{*}(x)=\frac{3}{4} a^{3 / 4} x^{-11 / 4} \quad \text { for } a \leqq x \leqq 1
$$

and

$$
f_{3}^{*}(x)=\frac{1}{4} a^{1 / 4} x^{-11 / 4} \quad \text { for } \alpha \leq x \leq 1,
$$

where $a=0.3577$. Moreover, $v_{1}=v_{2}=0.3577, v_{3}=0.2139, \alpha_{1}^{*}=\alpha_{2}^{*}=0$ and $\alpha_{3}^{*}$ 0.4427. (Note: the value of $b$ is 1 in Examples 1 and 2.)

Example 3. If $A_{1}(x)=x$ and $A_{2}(x)=A_{3}(x)=x^{3 / 2}$, then

$$
f_{1}^{*}(x)= \begin{cases}a x^{-3}, & a \leqq x \leqq b, \\ 0, & b<x \leqq 1,\end{cases}
$$

and

$$
f_{2}^{*}(x)=f_{3}^{*}(x)= \begin{cases}\frac{1}{2} a^{1 / 2} x^{-3}, & a \leqq x \leqq b, \\ \frac{3}{2} a^{1 / 2} b x^{-4}, & b<x \leqq 1,\end{cases}
$$

where $a=0.3892$ and $b=0.8268$. Furthermore, $\alpha_{1}^{*}=\alpha_{2}^{*}=\alpha_{3}^{*}=0, v_{1}=0.3892$ and $\mathrm{v}_{2}=\mathrm{v}_{3}=0.2428$.

Example 4. If $A_{1}(x)=x, A_{2}(x)=x^{3 / 2}$ and $A_{3}(x)=x^{2}$, then we have

$$
\begin{aligned}
& f_{1}^{*}(x)= \begin{cases}\frac{5}{4} a^{5 / 4} x^{-13 / 4}, & a \leqq x \leqq b, \\
0, & b<x \leqq 1,\end{cases} \\
& f_{2}^{*}(x)= \begin{cases}\frac{3}{4} a^{3 / 4} x^{-13 / 4}, & a \leqq x \leqq b, \\
2 a^{3 / 4} b^{5 / 4} x^{-9 / 2},\end{cases} \\
& f_{3}^{*}(x)= \begin{cases}\frac{1}{4} a^{1 / 4} x^{-13 / 4}, & b<x \leqq 1, \\
\frac{3}{2} a^{1 / 4} b^{5 / 4} x^{-9 / 2}, & a \leqq x \leqq b,\end{cases}
\end{aligned}
$$

where $a=0.4456$ and $b=0.9154$. Furthermore, we get $\alpha_{1}^{*}=\alpha_{2}^{*}=0$ and $\alpha_{3}^{*}=$ $0.4375, \mathrm{v}_{1}=0.4456, \mathrm{v}_{2}=0.2975$ and $\mathrm{v}_{3}=0.1986$.

Example 5. Let $A_{1}(x)=x^{1 / 2}, A_{2}(x)=x$ and $A_{3}(x)=x^{2}$. Then

$$
\begin{aligned}
& f_{1}^{*}(x)= \begin{cases}a x^{-5 / 2}, & a \leqq x \leqq b, \\
0, & b<x \leqq 1,\end{cases} \\
& f_{2}^{*}(x)= \begin{cases}\frac{1}{2} \alpha^{1 / 2} x^{-5 / 2}, & a \leqq x \leqq b, \\
2 a^{1 / 2} b^{3 / 2} x^{-4}, & b<x \leqq 1,\end{cases} \\
& f_{3}^{*}(x)= \begin{cases}0, & a \leqq x \leqq b, \\
b x^{-4}, & b<x \leqq 1,\end{cases}
\end{aligned}
$$


where $a=0.2975$ and $b=0.9269$. Moreover, $\alpha_{1}^{*}=\alpha \alpha_{2}^{*}=0, \alpha_{3}^{*}=0.9210, v_{1}=$ $0.5454, \mathrm{~V}_{2}=0.2975$ and $\mathrm{V}_{3}=0.1562$.

\section{Acknowledgements}

The author wishes to thank Professor M. Sakaguchi of Osaka University for his useful suggestions and valuable discussions. He also wishes to achnow1edge the referees for their comments, which have greatly improved the paper.

\section{References}

[1] Fox, M. and Kimeldorf, G.: Noisy Duels. SIAM Joumal on Applied Mathematics. Vo1. 17, No. 2 (1969), 353-361.

[2] Karlin, S.: Mathematical Methods and Theory in Games, Programming and Economics, II, Addison-Wesley, Reading, Massachusetts, 1959.

[3] Nash, J.: Non-Cooperative Games. Annals of Mathematics. Vol. 54, No. 2 (1951), 286-295.

[4] Restrepo, R.: Tactical Problems Involving Several Actions. Annals of Mathematics Studies, No. 39: Contributions to the Theory of Gomes, III (Eds. Dresher, M., Tucker, A.W. and Wolfe, P.). Princeton University Press, Princeton, 1957, 313-335.

[5] Sakaguchi, M.: Marksmanship Contests — Non-Zero-Sum Game of Timing. Mathematica Japonica. Vol. 22, No. 5 (1978), 585-596.

Tadashi KURISU:

Department of Applied Mathematics

Faculty of Enginnering Science

Osaka University

Toyonaka, Osaka, 560, Japan 


\section{プレイヤーが 3 人のサイレントな射撃コンテストについて}

次のような射撃コンテストの問題を考える。 $\mathrm{m}$ 人のプレイヤー1，2，, $\mathrm{m}$ がいて,各プレイヤー は一発づつ弾丸の入った銃を持っており，時刻０から1までの間に各自の標的をめがけて弾丸を発砲 するあのとする。プレイヤー $\mathrm{i}$ が時刻 $\mathrm{x}$ で発砲した時，弾丸が標的に当たる確率は $\mathrm{A}_{\mathrm{i}}(\mathrm{x})$ である。 $\mathrm{A}_{\mathrm{i}}(\mathrm{x})$ はプレイヤー $\mathrm{i}$ の精度関数と呼ばれ微分可能な増加関数で $\mathrm{A}_{\mathrm{i}}(0)=0, \mathrm{~A}_{\mathrm{i}}(1)=1$ を满た すおのとする。各プレイヤーは全てのプレイヤーの精度関数を予め知っており， m人のプレイャーの うちで最初に標的に当てたプレイャーの利得を+1とし, 他のプレイャーの利得は 0 とする。このゲ 一ムでは各プレイヤーは精度がよくなるように発砲時刻をできるだけ遅らせようとするが，同時に他 のプレイヤーが標的に当てるよりも先に発砲した方が有利であり，両者のバランスをとることが重要 である。この問題は，連続型ゲーム上して代表的な決闘ゲームの非零和 $\mathrm{m}$ 人ゲームへの拡張になって おり，行動を起すタイミングをどのようにとればよいかという現実に多く存在する状況をモデル化し たものである。

決闘ゲームと同様にこのゲームであ1 人のプレイヤーが発砲したことが他のプレイヤーにわかるか わからないかが重要である。あるプレイヤーが発砲すれば直ちにこれが他のプレイヤーにわかる時, コンテストはnoisyであるといい，プレイヤーが発砲しても，他のどのプレイヤーもこれがわから ない時,コンテストはsilentであるという。決闘ゲームについては既に種々の研究がある。又, 射 撃コンテストについても $\mathrm{m}=2$ の場合执よび $\mathrm{m}$ は一般で $\mathrm{A} i \mathrm{x})=\mathrm{x}$ の silent については研究 されている。

本論文では $\mathrm{m}=3$ の s l l ent コンテストについて考察する。一般の精度関数に対して各プレイヤ 一の均衡戦略と, 均衡戦略による各プレイヤーの期待利得を求めた。均衡戦略の形は

$\mathrm{A}_{1}(\mathrm{x}) / \mathrm{A}_{2}(\mathrm{x}) \mathrm{A}_{3}(\mathrm{x}), \mathrm{A}_{2}(\mathrm{x}) / \mathrm{A}_{1}(\mathrm{x}) \mathrm{A}_{3}(\mathrm{x}), \mathrm{A}_{3}(\mathrm{x}) / \mathrm{A}_{1}(\mathrm{x}) \mathrm{A}_{2}(\mathrm{x})$ が単調减少であるか, あるいはこのうちの1つが単調増加であるかによって変化することがわかる。最後に，種々の精度関 数に対して各プレイヤーの均衡戦略と期待利得を求め結果を例示した。 